\title{
Feed Efficiency Estimates in Cattle: The Economic and Environmental Impacts of Reranking
}

\author{
Albert Boaitey $^{1}$, Ellen Goddard ${ }^{1}$, Sandeep Mohapatra ${ }^{1}$ John Crowley ${ }^{2,3}$ \\ ${ }^{1}$ Department of Resource Economics and Environmental Sociology, University of Alberta, Edmonton, Canada \\ ${ }^{2}$ Livestock Gentec-AFNS, University of Alberta, Edmonton, Canada \\ ${ }^{3}$ Canadian Beef Breeds Council, Calgary, Canada \\ Correspondence: Albert Boaitey, Department of Resource Economics and Environmental Sociology, University \\ of Alberta, Edmonton, T6G-2H1, AB Canada. Email: boaitey@ualberta.ca
}

Received: December 21, 2016

Accepted: January 24, 2017 Online Published: February 21, 2017

doi:10.5539/sar.v6n2p35

URL: https://doi.org/10.5539/sar.v6n2p35

\begin{abstract}
This paper proposes the application of hierarchical models to the assessment of feed efficiency in beef cattle. Using a large dataset comprising 5600 cattle assembled from different experimental studies, feed efficiency rankings of cattle were estimated using the proposed approach. This was compared to more commonly used linear, and nonlinear estimators. A phenotypic selection scheme that selects cattle at the means of different percentiles was developed to illustrate potential economic and environmental outcomes resulting from changes in feed efficiency rankings. The former involved the specification of a multi-year stochastic farm simulation model. In general, our results show that improved feed efficiency is associated with positive economic and environmental benefits. A unit reduction in feed intake ( $\mathrm{kg}$ as fed/day) is associated with an average increase of $\$ 13.23$ in net returns and 33.46 tonnes reduction in emission at the end of the feeding period. We also find that feed efficiency ranking of cattle is sensitive to estimation approach. The within percentile mean estimates of the hierarchical model were comparable to the conventional linear estimator. There were, however, deviations at the tails of feed efficiency distributions where selection is most likely to occur.
\end{abstract}

Keywords: feed efficiency, residual feed intake, methane emissions, hierarchical estimates

\section{Introduction}

Profit margins in cattle feeding are thin and feed cost constitutes a major component of total production cost (Dilenzo and Lamb, 2012). In fragmented production systems where cattle breeding and feeding are distinct operations, reduced margins from higher feed costs at the feeder end means lower valuation of weaned calves. Feed utilization by cattle is also linked with methane from enteric fermentation. Methane is an important greenhouse gas with an estimated global warming potential ${ }^{1}$ of $28-36$ times that of carbon (Environmental Protection Agency, 2016). This implies that improvement in feed efficiency has important environmental and economic implications for cattle producers. This notwithstanding, improvements in the trait has occurred at a much slower pace as compared to other traits. Figure 1 shows genetic trends in birthweight, weaning weight, feed intake and feed efficiency (measured as residual average daily gain) in Angus cattle. Further, the pork and poultry sectors have seen much higher improvements in the trait as compared to cattle (Basarab, Baron, López-Campos, Aalhus, Haugen-Kozyra, \& Okine, 2012).

\footnotetext{
${ }^{1}$ Over 100-year period.
} 


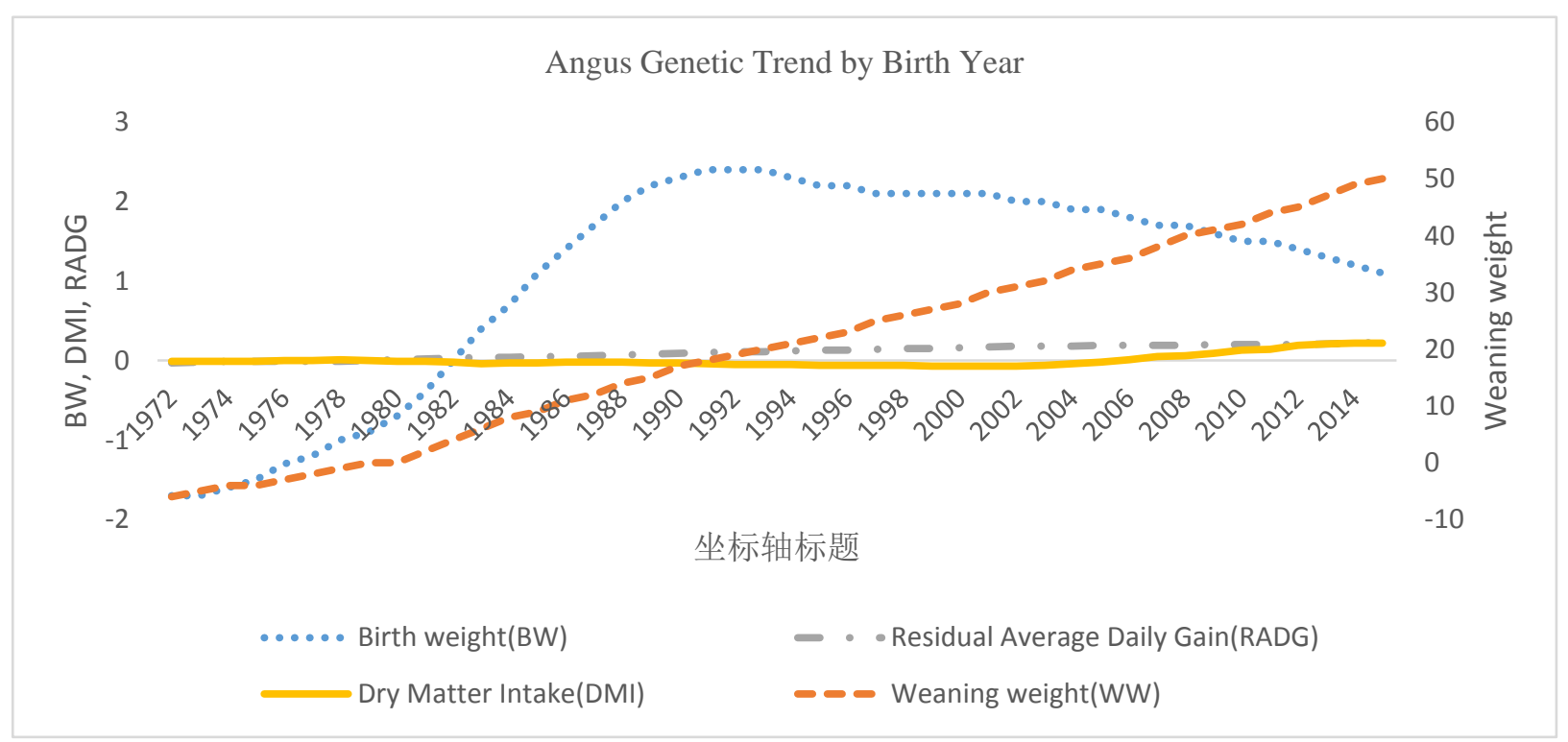

Figure 1. Angus cattle: Trends in selected traits (Data source: Angus Beef, 2015)

Improvements in feed efficiency through breeding requires the identification of high performing individuals and the linking of this information back to their parents (bulls and dams) and/or their genomic information. In breeding programs this requires both genotypic and phenotypic data. The latter refers to actual feed intake and performance data. Feed intake is affected by both genetic and environmental factors. This suggests that accurately accounting for these different sources of heterogeneity is critical for several reasons. The most important being that errors in the feed efficiency estimate of an individual can distort its ranking within a cohort of cattle. This can, in turn, affect the valuation of performance of the parents of these animals leading to errors in selection. The intertemporal nature of breeding decisions means the economic and environmental implications of these errors can be far-reaching.

Studies (e.g. Robinson, 2005a; Robinson 2005b; Berry \& Crowley, 2013) have evaluated aspects of RFI estimation. Robinson (2005a) examined the impact of measurement errors in covariates in the context of residual feed intake estimation. Errors in covariates were found to be a significant source of bias in the resulting coefficient estimates. Approaches such as inverse regression were suggested as a means of correcting for the effect of these errors (Robinson 2005a). Robinson (2005b) compared different estimates of weight gain using feed efficiency data. Berry and Crowley (2013) noted possible nonlinear relationships between feed intake, average daily gain (ADG) and metabolic mid-weight (MWT) amongst diverse populations and animals with inferior genetic merit for these traits. Basarab, Price, Aalhus, Okine, Snelling and Lyle (2003) found evidence of the possibility of re-ranking cattle based on efficiency estimates from the different linear models used. The use of more robust empirical techniques and the impact of errors in estimation, as it pertains to the economic and environmental wellbeing of beef farms, have not been previously explored.

In the light of the foregoing, this paper has two objectives. First, we estimate and rank a large dataset of cattle by feed efficiency estimator using a multi-level estimation technique and compare rankings with that of more commonly used approaches. Second, we evaluate the economic and environmental consequences resulting from changes in the feed efficiency ranking of cattle by the different estimation approaches. From this analysis, we can quantify the implications of model accuracy. In the economic analysis, we assess the impact of selection at different percentiles on profits using a stochastic farm model. We also track methane from enteric fermentation sources and evaluate differences in emissions by feed efficiency estimator.

The rest of the paper proceeds as follows. A brief overview of the existing literature on the measurement of feed efficiency is first presented. This is followed by a description of empirical approach and data sources. The results of the analysis are then presented. The final section provides concluding remarks.

\subsection{Feed Efficiency, Measurement and Improvement}

Feed efficient cattle consume less feed per unit measure of beef produced. Commonly used estimates of feed efficiency include: feed conversion ratios (FCR) (Brody, 1945) and residual feed intake (RFI) (Koch, Swiger, Chambers, \& Gregory, 1963). Although extensively used in the past, the former has been less favored in recent years as a result of unfavorable correlations between FCR and its component traits (Nkrumah, Basarab, Price, 
Okine, Guercio, \& Moore, 2004; Archer, Richardson, Herd \& Arthur, 1999). Residual feed intake (RFI), estimated as the difference between actual animal feed intake and predicted feed intake, is the prevalent measure of feed efficiency across the different livestock production systems (Koch, Swiger, Chambers, \& Gregory1963; Archer, Richardson, Herd \& Arthur, 1999; Rauw, Soler, Tibau, Reixach \& Raya, 2006). Differences in RFI capture variations in the efficiency with which individual animals utilize feed for maintenance and production (Basarab et al., 2003; Johnson, Chewning \& Nugent, 1999). Lower RFI values are more desirable since they imply more efficient conversion of feed into meat per unit of intake. Predicted feed intake is typically estimated as a linear regression of actual animal feed intake on a set of covariates such as average daily gain, mid metabolic body weight and measures of meat composition such as back fat (Hoque, Kadowaki, Shibata, Oikawa \& Suzuki, 2009).

Previous studies (e.g. Arthur, Archer, Johnston, Herd, Richardson, \& Parnell, 2001; Herd \& Bishop, 2000; Basarab et al., 2003) have examined residual feed intake for different categories of beef cattle. This residual portion of feed intake forms the basis for identifying relatively more efficient-cattle with lower (negative) RFIs. It has been suggested that RFI could represent variations in metabolic processes which determine feed efficiency (Brelin \& Brannang, 1982; Korver, 1988). As errors from the regression of covariates that capture size and growth, residual feed intake is phenotypically independent of these production traits. This implies that there will be little correlated effects of the selection for feed efficiency. Arthur et al. (2001) in a study of feed efficiency in Angus cattle, estimated a linear regression model of feed intake on metabolic weight and ADG controlling for group and sex effects. Residual feed intake was derived as the difference between an animal's actual feed intake and predicted feed intake given its' size and growth. Additionally, the study found evidence of genetic and phenotypic independence between RFI and component traits. Herd and Bishop (2000) assessed the existence of genetic variation in RFI in young bulls and the phenotypic and genotypic relationships between RFI and other important production traits such as mature cow size. The predicted feed equation was estimated as a linear regression of feed intake (FI) on MWT and ADG. Archer (1999) estimated RFI as residuals from the linear regression of feed intake on ADG and MWT. To capture possible heterogeneity across animals resulting from gender and treatment, separate models were estimated for each gender within each test cohort. Arthur, Renand and Krauss (2001) examined genetic and phenotypic relationships between different feed efficiency and growth measures in young Charolais bulls.

While measurement is a crucial aspect of the assessment of feed efficiency an equally important consideration is improvements in trait. Improvements in feed efficiency can be achieved in a variety ways. Table 1 is a summary of selected approaches. These include: through selection, nutrition, the use of growth promotants and management practices. Nutrition related practices include changes in diet composition. For example, the inclusion of higher levels of concentrate in feed is associated with higher feed conversion rates. Meyers (1999) reported a $25 \%$ increment in feed efficiency from cattle fed $90-100 \%$ concentrate as compared to $60 \%$ concentrate diets. The use of growth promotants such as implants, ionophores and beta-agonists is associated with higher levels of feed efficiency (4-23\%). In addition to these, evidence from other studies (Myers, Faulkner, Ireland, Berger, \& Parrett, 1999; Schoonmaker, Fluharty \& Loerch, 2004; Barker-Neef, Buskirk, Black, Doumit, $\&$ Rust, 2001) that examined the effect of management practices on the feed efficiency report a negative relationship between weaning time and feed efficiency. In general, feed efficiency is higher in early weaned calves-9-8\%. The reported rate of improvement in feed efficiency from selection (i.e. $0.75-1 \%$ ) is relatively low in magnitude as compared to the other practices outlined. However, the genetic change is per year and is cumulative and permanent. 
Table 1. Summary of selected approaches to increasing feed efficiency in beef cattle

\begin{tabular}{|c|c|c|c|c|}
\hline Approach & & Improvements in feed efficiency & $\begin{array}{l}\text { Type of } \\
\text { cattle }\end{array}$ & Reference \\
\hline \multirow[t]{2}{*}{ Selection } & \multirow[t]{2}{*}{$\begin{array}{l}\text { Select for feed } \\
\text { efficiency } \\
\text { (low RFI) }\end{array}$} & $\begin{array}{l}0.75-1 \% \text { per year improvement in feed } \\
\text { efficiency }\end{array}$ & Calves & $\begin{array}{l}\text { Basarab, Beauchemin, Baron, } \\
\text { Ominski, Guan, Miller and Crowley } \\
\text { (2013) }\end{array}$ \\
\hline & & $\begin{array}{l}1.247 \mathrm{~kg} / \text { day }(<\text { feed intake) divergence } \\
\text { in feed efficiency from high and low } \\
\text { RFI bulls }\end{array}$ & Calves & Arthur et al., (2001). \\
\hline \multirow[t]{6}{*}{$\begin{array}{l}\text { Nutrition and } \\
\text { Growth } \\
\text { promotants }\end{array}$} & \multirow[t]{2}{*}{$\begin{array}{l}\text { Diet } \\
\text { Concentration }\end{array}$} & $\begin{array}{l}\text { Gain: Feed ratio } \\
0.19 \text { (concentrate) } \\
0.18 \text { (pasture) } \\
\end{array}$ & $\begin{array}{l}\text { Finishing } \\
\text { phase }\end{array}$ & $\begin{array}{l}\text { Myers, Faulkner, Ireland, Berger, and } \\
\text { Parrett, (1999). }\end{array}$ \\
\hline & & $\begin{array}{l}\text { Feed efficiency: } \\
25 \%>\quad(90-100 \% \text { concentrate diet }) \\
\text { versus }(60 \% \text { concentrate diet })\end{array}$ & $\begin{array}{l}\text { Finishing } \\
\text { phase }\end{array}$ & $\begin{array}{l}\text { Fluharty, Loerch, Turner, Moeller and } \\
\text { Lowe (2000) }\end{array}$ \\
\hline & \multirow[t]{4}{*}{$\begin{array}{l}\text { Growth } \\
\text { Promotants }\end{array}$} & $\begin{array}{l}\text { 8.8\%(implants) } \\
3.6 \% \text { (Ionophores) } \\
12.6 \% \text { (Beta-agonists) }\end{array}$ & $\begin{array}{l}\text { Feedlot } \\
\text { cattle }\end{array}$ & Lawrence and Ibarburu (2000). \\
\hline & & $\begin{array}{l}\text { Gain: Feed ratio } \\
0.24 \text { (cattle raised with growth } \\
\begin{array}{l}\text { promotants) } \\
0.18 \text { (cattle raised without growth } \\
\text { promotants) }\end{array}\end{array}$ & $\begin{array}{l}\text { Feedlot } \\
\text { cattle }\end{array}$ & $\begin{array}{l}\text { Cooprider, Mitloehner, Famula, } \\
\text { Kebreab, Zhao and Van Eenennaam, } \\
(2011)\end{array}$ \\
\hline & & $\begin{array}{l}\text { Gain: Feed ratio } \\
0.17 \text { (Implanted steers) } \\
0.15 \text { (Non-implanted steers) } \\
\end{array}$ & steers & $\begin{array}{l}\text { Wileman, Thomson, Reinhardt and } \\
\text { Renter, (2009) }\end{array}$ \\
\hline & & $\begin{array}{l}14 \% \\
23 \%\end{array}$ & $\begin{array}{l}\text { Steers in } \\
\text { growing } \\
\text { phase } \\
\text { Steers in } \\
\text { finishing } \\
\text { phase }\end{array}$ & $\begin{array}{l}\text { Berthiaume, Mandell, Faucitano and } \\
\text { Lafreniere, (2006). }\end{array}$ \\
\hline \multirow[t]{2}{*}{$\begin{array}{l}\text { Management } \\
\text { practices }\end{array}$} & \multirow[t]{2}{*}{ Weaning age } & $\begin{array}{l}\text { Gain: Feed ratio } \\
0.20 \text { (90 days);0.18(152 days); } \\
0.16(215 \text { days })\end{array}$ & Steer calves & $\begin{array}{l}\text { Myers, Faulkner, Ireland, Berger, and } \\
\text { Parrett, (1999). }\end{array}$ \\
\hline & & $\begin{array}{l}\text { Feed conversion ratio(FCR) } \\
9-8 \% \text { (103 days) }\end{array}$ & Steer calves & $\begin{array}{l}\text { Barker-Neef, Buskirk, Black, Doumit, } \\
\text { and Rust, (2001); Schoonmaker, } \\
\text { Fluharty and Loerch, (2004). }\end{array}$ \\
\hline
\end{tabular}

Note: different units of the magnitudes of reduction limits comparability

\section{Methods}

The collection of actual feed intake data of cattle imbedded in different treatment cohorts often requires the pooling of data from multi-sources. A major challenge in analyzing datasets with large sources of heterogeneity is the potential to over-fit the data due to the incorporation of a large set of treatment effects. This context however, provides the ideal condition for the application of estimation techniques that are more adapt to modelling heterogeneity. Gelman (2006) noted that hierarchical models represent a more robust approach when juxtaposed against standard completely pooled and unpooled regression in the analysis of nested data. Previous applications in beef cattle include: the assessment of culling risk (Babcock, Cernicchiaro, White, Dubnicka, Thomson, Ives, Scott, Milliken \& Renter, 2013); assessment of variances in average daily gain (Cernicchiaro, Renter, Xiang, White \& Bello, 2013).

We propose the application of a hierarchical model approach to the assessment of cattle feed intake data. In estimating the hierarchical model, it is assumed that animals (level 1) are nested within treatment cohorts (level 2) which are nested within the location of the feeding experiment (level 3). The inclusion of level 3 is an attempt to capture region specific idiosyncratic effects common with multi-source dataset. Following Hedeker and Gibbons 
(1994), the three level model is specified as:

$$
\begin{aligned}
& D F I_{i j k}=\alpha_{0}+\alpha X_{i j k}+V_{k}+u_{j k}+e_{i j k} \\
& v_{k} \square N\left(0, \sigma_{v}^{2}\right) \\
& u_{j k} \square N\left(0, \sigma_{u}^{2}\right) \\
& e_{i j k} \square N\left(0, \sigma_{e}^{2}\right)
\end{aligned}
$$

where $D F I_{i j k}$ is the feed intake for cattle ${ }_{i}(i=1, \ldots, n)$ in the contemporary group $j^{j}(j=1, \ldots, 122)$ and source ${ }_{k}(k=1, \ldots, 3), \alpha_{0}, \alpha$ are estimated parameters, ${ }^{v_{k}}$ represents the effect of the ${ }_{k t h}$ source, $u_{j k}$ denoted the contemporary group effect of the ${ }^{j}$ group, $e_{i j}$ is the animal level residual term. Estimates of the variance components of the model are also reported. Based on these estimates, Variance Partition Coefficients (VPCs) that measure the proportion of the variation in feed intake attributable to each level within the 3-level hierarchical framework are estimated. For example, VPC at the animal level ${ }^{(e)}$ :

$$
V P C_{e}=\frac{\sigma_{e}^{2}}{\sigma_{e}^{2}+\sigma_{u}^{2}+\sigma_{k}^{2}}
$$

where subscripts ${ }_{k}$ and $u$ denote data source and contemporary respectively, and variance is $\sigma^{2}$.For each animal $i$, the covariates in the feed intake equation are average daily gain and mid metabolic body weight. In addition to the hierarchical model both linear and quadratic functions are estimated. The breed, sex and contemporary group effects are included as dummy variables. Contemporary group refers to animals in the same treatment cohort. For each of these estimators, the corresponding RFI estimate for the ith cattle is derived as the difference between actual and predicted feed intake:

$$
R F I_{i}=D F I_{i}-\hat{D F I} I_{i}
$$

For a given animal $i, R F I=$ residual feed intake, $D F I$ actual feed intake, $\hat{D F I}$ predicted feed intake.

Based on these estimates, the resulting RFI distributions are derived. To evaluate the potential impacts of selection based on different estimators, the economic and environmental effects of phenotypic changes in RFI at different percentiles are estimated and compared. Net returns from cattle feeding are simulated from a 25 -year model that accounts for stochasticity in feed and cattle prices. For each RFI estimation approach $i$, net returns are estimated as:

$$
N R_{i}=p_{f} y_{f}-p_{w} y_{w}-F C\left(D M I, r f_{i}, f_{p}\right)-O C
$$

where NR is net returns $p_{f}$ is finisher price of cattle, $y_{f}$ is cattle at finisher weight, $p_{w}$ is the price at purchase weight, $y_{w}$ cattle at purchased weight, $F C$ is feed cost, $D M I$ is dry matter intake, $r f i$ is residual feed intake, $f_{p}$ is the price of feed and $O C$ refers to other production costs(veterinary, bedding, transportation costs). Net returns are discounted at $5 \%$.

Cattle are assumed to be initially placed on a backgrounding diet from weaning (550 lbs) to $750 \mathrm{lbs}$ before being transferred to a finisher diet. Cattle are finished at $1225 \mathrm{lbs}$ (Carlberg \& Brown 2001). It is assumed that the feeding operation has 5600 animals. Methane from enteric fermentation emitted over the feeding period is estimated as:

$$
\text { Emissions }_{\text {cattle }}=\frac{\sum\left(\text { cattle }_{i} * D O F * D M I_{i} * G E_{\text {Diet }} * E F_{\text {Enteric }_{i}}\right)}{E C_{\text {Methane }}}
$$

where Emissions is total emissions from enteric fermentation, cattle is number of cattle, DOF is days on feed, $D M I$ is dry matter intake, $G E$ is gross content of diet assumed to be $18.45 \mathrm{MJ} / \mathrm{kg}$ dry matter, $E F$ is emission factor for enteric fermentation assumed to be $6.5 \%$ and $E C$ is the energy content of methane. The quantification equation is taken from the Alberta low RFI protocol (Environment Alberta, 2012).

\subsection{Data and Data Sources}

Feed intake data was collected from three research projects: Agriculture and Agri-Food Canada's(AAFC) Phenomic Gap project (PG1), the University of Alberta at the Kinsella ranch (KIN) and the Elora test station at the University of Guelph (UOG).The PG1 dataset consisted of animal performance tested (i.e. measure for feed intake concurrently with growth rate and body composition) between 2003 and 2012 at the AAFC research station at Lacombe, Olds College, and three other commercial feedlots all in Alberta. Sire breeds were Angus 
(AN), Charolais (CH), Gelbveih (GV). Average age at the start of test was 311 days. The test period, preceded by 28-24 day adjustment period. Data on cattle in the KIN dataset was collected over the period 2007-2011.Average age at the start of test was 222 days. The UOG dataset comprised Angus, Charolais, Limousin, Piedmontese and Simmental sired animals that were performance tested between 1999 and 2007. Animals typically 200 days old were performance tested at the Elora Beef Research center (EBRC) after a 28-35 day adaptation period. Other breeds in the sample included Kinsella Hybrid (HY), Simmental(SM), Red Angus (AR), Shorthorn (SS) and two strains of cattle (denoted TX and M4). A detailed description of the data and methods of data collection can be found in previous studies (Basarab, Colazo, Ambrose, Novak, Mccartney \& Baron, 2011; Durunna, Mujibi, Goonewardene, Okine, Basarab, Wang \& Moore, 2011; Lu, Miller, Sargolzaei, Kelly, Vander Voort, Caldwell, Wang, Plastow, Moore, 2013).

Data from multiple sources are used in the simulation analysis. Information on feed requirements and entry and exit weights for the feeding phase of the model were obtained from the Alberta beef cow-calf manual (Alberta Agriculture and Food, 2008). Data on overwinter feeding cost of cows and the feeding phase (i.e. backgrounding and finisher) is obtained from Alberta Agriculture and Rural Development (2004) and the Feedlot Investment Risk Simulation decision making tool.

\section{Results}

Tables 2 captures the descriptive statistics of DFI, MWT, ADG cattle and feed prices for the overall sample. Mean feed intake for the entire sample is approximately $9.15 \mathrm{~kg} / \mathrm{day}$, over the range of $4.07 \mathrm{~kg} / \mathrm{day}(\mathrm{min})$ and $15.54 \mathrm{~kg} /$ day (max). Mean MWT and ADG were $93.51 \mathrm{~kg}$ and $1.47 \mathrm{~kg} /$ day respectively. In general, steer prices were higher than heifer prices for both weaned and finished prices. Cattle prices were also inversely related with weight reflecting the so-called price slide. The mean feed barley price (\$/tonne) was approximately $\$ 158$. The cost of barley silage (i.e. $\$ 40$ ) was about a third of the feed barley price. Further $73 \%$ of the cattle in the sample were male, whilst heifers constituted the remaining $27 \%$. The dominant breeds were HY (12\%), AN (12\%), HE $(30 \%)$ and TX $(22 \%)$.

Table 2: Summary statistics of feed intake, cattle and feed price data.

\begin{tabular}{lcll}
\hline Variable & Mean & Min & \multicolumn{1}{l}{ Max } \\
\hline \multicolumn{4}{c}{ Feed intake } \\
\hline DFI(Kg/day) & 9.15 & 4.07 & 15.54 \\
ADG(Kg/day) & 1.47 & 0.40 & 2.91 \\
MWT(kg) & 93.51 & 57.01 & 136.27 \\
\hline \multicolumn{4}{c}{ Economic indicators } \\
\hline 550 lbs steer (\$cwt) & 108.18 & 74.88 & 191.67 \\
550 lbs heifer $(\$ / \mathrm{cwt})$ & 104.91 & 74.49 & 185.65 \\
900 lbs steer (\$cwt) & 103.64 & 92.52 & 145.72 \\
900 lbs heifer (\$/cwt) & 101.71 & 93.14 & 117.46 \\
Barley (\$/tonne) & 158.15 & 98.06 & 268.31 \\
Barley silage (\$/tonne) & 41.30 & 25.70 & 70.15 \\
\hline
\end{tabular}

Table 3 shows the results of the multi-level model. It is assumed that cattle (level 1) are nested within treatment cohorts (level 2) which are nested within the location of the feeding experiment (level 3). In addition to coefficient estimates, the variance components and the variance partition coefficients are also reported. 
Table 3. Results of multi-level regression estimates

\begin{tabular}{ll}
\hline Variable & coefficient \\
\cline { 2 - 2 } Constant & 1.243 \\
ADG & $1.387(\mathrm{P}=0.01)$ \\
MWT & $0.076(\mathrm{P}=0.01)$ \\
Sex & $0.086(\mathrm{P}=0.01)$ \\
HY & $-1.393(\mathrm{P}=0.01)$ \\
AN & $-1.660(\mathrm{P}=0.01)$ \\
CH & $-1.829(\mathrm{P}=0.01)$ \\
HE & $-1.686(\mathrm{P}=0.01)$ \\
TX & $-2.148(\mathrm{P}=0.01)$ \\
GV & $-1.654(\mathrm{P}=0.01)$ \\
M4 & $-3.170(\mathrm{P}=0.01)$ \\
AR & $-1.921(\mathrm{P}=0.01)$ \\
SM & $-1.862(\mathrm{P}=0.01)$ \\
SS & $-1.913(\mathrm{P}=0.01)$ \\
LM & $-1.969(\mathrm{P}=0.01)$ \\
PP & $1.981(\mathrm{P}=0.01)$ \\
Residual Variance & 0.454 \\
Treatment Variance & 0.860 \\
Source Variance & $1.34 \mathrm{e}-12$ \\
$V P C$ & 0.35 \\
$V P C_{u}$ & 0.65 \\
$V P C_{k}$ & 0 \\
\hline LR test vs. Linear Chi2(2) & $4635.41(\mathrm{P}=0.01)$ \\
Log likelihood & -6305.80 \\
\hline
\end{tabular}

Notes: p-value in parenthesis

From Table 3, ADG and MWT positively affect feed intake. A unit increase in MWT is associated with a 0.08 increase (kg/day) in feed intake. A unit change in ADG is associated with a much higher response in feed intake-1.4 kg/day. In general, it seems that the greatest heterogeneity occurs at the contemporary group level. This is followed by the individual level. The source variance was least. Consequently, the VPC estimates were 0 , 65 and $35 \%$ at the source, contemporary group and animal levels respectively. This suggests that $35 \%$ of the differences in feed intake are observable at the animal level as compared to $(65 \%)$ at the contemporary group level. The breed and gender effects are all significant implying that controlling for these effects was indeed appropriate.

In Table 4, the results of the linear and nonlinear model estimates are presented. In these models, the treatment, breed and sex effects are included as dummy variables. The coefficient estimates of the linear model are generally consistent with the multi-level model although the magnitudes differ slightly. The coefficient estimate for MWT is marginally greater than the corresponding estimate in the multi-level model, the reverse applies to ADG. Also from Table 4, the nonlinear specification does not improve model fit. For each of the reported estimates, the feed efficiency score of each animal is calculated as the difference between actual and predicted feed intake. 
Table 4. Results of linear and non-linear multivariate estimates

\begin{tabular}{lll}
\hline Variable & $\begin{array}{l}\text { Linear } \\
\text { Coefficient }\end{array}$ & $\begin{array}{l}\text { Quadratic } \\
\text { Coefficient }\end{array}$ \\
\hline Constant & $-2.50(\mathrm{P}=0.01)$ & 1.197 \\
ADG & $1.403(\mathrm{P}=0.01)$ & $1.194(\mathrm{P}=0.01)$ \\
MWT & $0.076(\mathrm{P}=0.01)$ & $0.0846(\mathrm{P}=0.01)$ \\
ADG*MWT & & $0.013(\mathrm{P}=0.01)$ \\
ADGSQ & & $-0.33(\mathrm{P}=0.01)$ \\
MWTSQ & & -0.000 \\
Sex & 0.113 & 0.101 \\
HY & 0.214 & $-3.022(\mathrm{P}=0.01)$ \\
AN & -0.021 & $-3.250(\mathrm{P}=0.01)$ \\
CH & -0.263 & $-3.495(\mathrm{P}=0.01)$ \\
HE & 0.100 & $-3.335(\mathrm{P}=0.01)$ \\
TX & $-1.092(\mathrm{P}=0.05)$ & $-4.383(\mathrm{P}=0.01)$ \\
GV & & $-3.236(\mathrm{P}=0.01)$ \\
M4 & & $-3.537(\mathrm{P}=0.01)$ \\
AR & -0.213 & $-3.540(\mathrm{P}=0.01)$ \\
SM & -0.210 & $-3.438(\mathrm{P}=0.01)$ \\
SS & -0.279 & $-3.487(\mathrm{P}=0.01)$ \\
LM & -0.331 & $-3.850 .01)$ \\
PP & $-0.349(0.10)$ & $-3.579(\mathrm{P}=0.85$ \\
\hline R & & \\
\hline & & \\
\hline
\end{tabular}

Notes: p-value in parenthesis

Feed efficiency scores ranged from a low of $-4.02 \mathrm{~kg}$ (as fed/day) to a higher $4.16 \mathrm{~kg}$ (as fed/day). This implies that the most efficient cattle consumed $4.02 \mathrm{~kg}$ less feed when controlled for ADG and MWT as compared to the least efficient animal which eats $4.16 \mathrm{~kg}$ of feed more. The distribution of feed efficiency scores was comparable across the different estimators but the rankings of cattle differed.

\section{Frequency of changes in ranking}

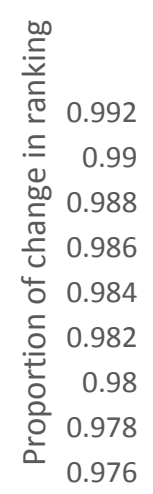

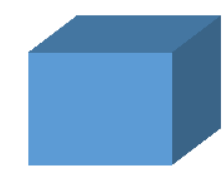

multi-level vrs linear

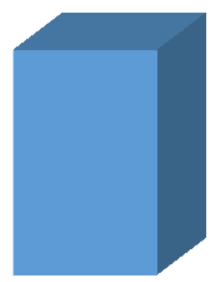

linear vrs quadratic

Estimation approach

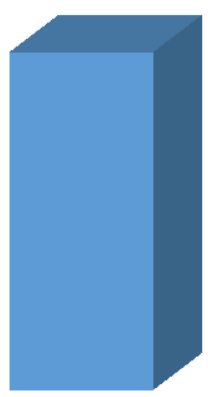

multi-level vrs quadratic

Figure 2. Comparison of the frequency of change in ranking by estimation approach 
From Figure 2, the feed efficiency rankings of approximately $98-99 \%$ of cattle assessed changed by estimation approach. This translates to changes in 5500 animals in the total sample of 5600 animals. The greatest variability was between the multi-level and quadratic estimate whilst the multi-level and linear model showed the least variation in ranking. This notwithstanding, the results imply that estimation approach significantly impacts the feed efficiency scores and rankings of cattle.

To further illustrate the effect of the changes in ranking from the different estimates, a stochastic multi-year simulation model that tracks net returns and methane emissions from enteric fermentation was estimated. The size of the operation is assumed to be 5906 calves. For each estimator three intensities of selection are assessed1,5 and $10 \%$. From the results of the multi-level estimates this translates to reductions $(\mathrm{kg} / \mathrm{day}$ as fed) of $2.30(1 \%), 1.57(5 \%)$ and $1.24(10 \%)$. The corresponding rates of reduction $(\mathrm{kg} / \mathrm{day}$ as fed) in the linear model are: $2.28(1 \%), 1.56(5 \%)$ and $1.23(105 \%)$. The rates of reduction (kg/day as fed) for the nonlinear estimation are: $2.29(1 \%), 1.55(5 \%)$ and $1.23(10 \%)$. Table 5 is a summary of results.

Table 5. Economic and Environmental Analysis

\begin{tabular}{|c|c|c|c|c|}
\hline & $\begin{array}{l}\text { Mean } \\
(\$ / \text { calf })\end{array}$ & $\begin{array}{l}\text { Min } \\
(\$ / \text { calf })\end{array}$ & $\begin{array}{l}\text { Max } \\
(\$ / \text { calf })\end{array}$ & methane from enteric fermentation(tonnes) \\
\hline Base & 86.42 & 9.96 & 191.13 & 696.54 \\
\hline \multicolumn{5}{|c|}{$1 \%$} \\
\hline multi-level & 116.85 & 42.82 & 220.11 & 619.56 \\
\hline linear & 116.68 & 42.64 & 219.95 & 619.58 \\
\hline quadratic & 107.31 & 32.53 & 211.03 & 643.68 \\
\hline \multicolumn{5}{|c|}{$5 \%$} \\
\hline multi-level & 107.14 & 32.34 & 210.86 & 644.12 \\
\hline linear & 107.09 & 32.29 & 210.81 & 644.24 \\
\hline quadratic & 102.91 & 27.77 & 206.83 & 654.82 \\
\hline \multicolumn{5}{|c|}{$10 \%$} \\
\hline multi-level & 102.76 & 27.61 & 206.69 & 655.2 \\
\hline linear & 102.76 & 27.61 & 206.69 & 655.2 \\
\hline quadratic & 102.72 & 27.57 & 206.66 & 655.29 \\
\hline
\end{tabular}

From the multi-level model, higher feed efficiency is associated with improved economic and environmental outcomes. As compared to the base scenario, profits increase by: $\$ 30.43,20.72$ and 18.28 at 1,5 and $10 \%$ respectively. This corresponds to approximately 35,24 and $21 \%$ improvement in net returns. The corresponding reductions in methane emissions (tonnes) resulting from improvements in feed efficiency is 76.98, 52.42 and 41.34. Expectedly, both environmental and economic benefits increase as selection approaches the tail of the distribution.

Changes in methane and net returns from the multi-level estimates were more comparable to the linear estimator than the non-linear estimator. As showed in Figure 3, the differences between these measures were 0\%, $0.24 \%$ and $0.6 \%$ for the linear model as compared $0-35 \%$ in the case of the nonlinear estimator. The highest differences occur at the upper tail of the distribution. It seems that as one moves further away from the tails of the distribution, the impact of estimation approach reduces. 


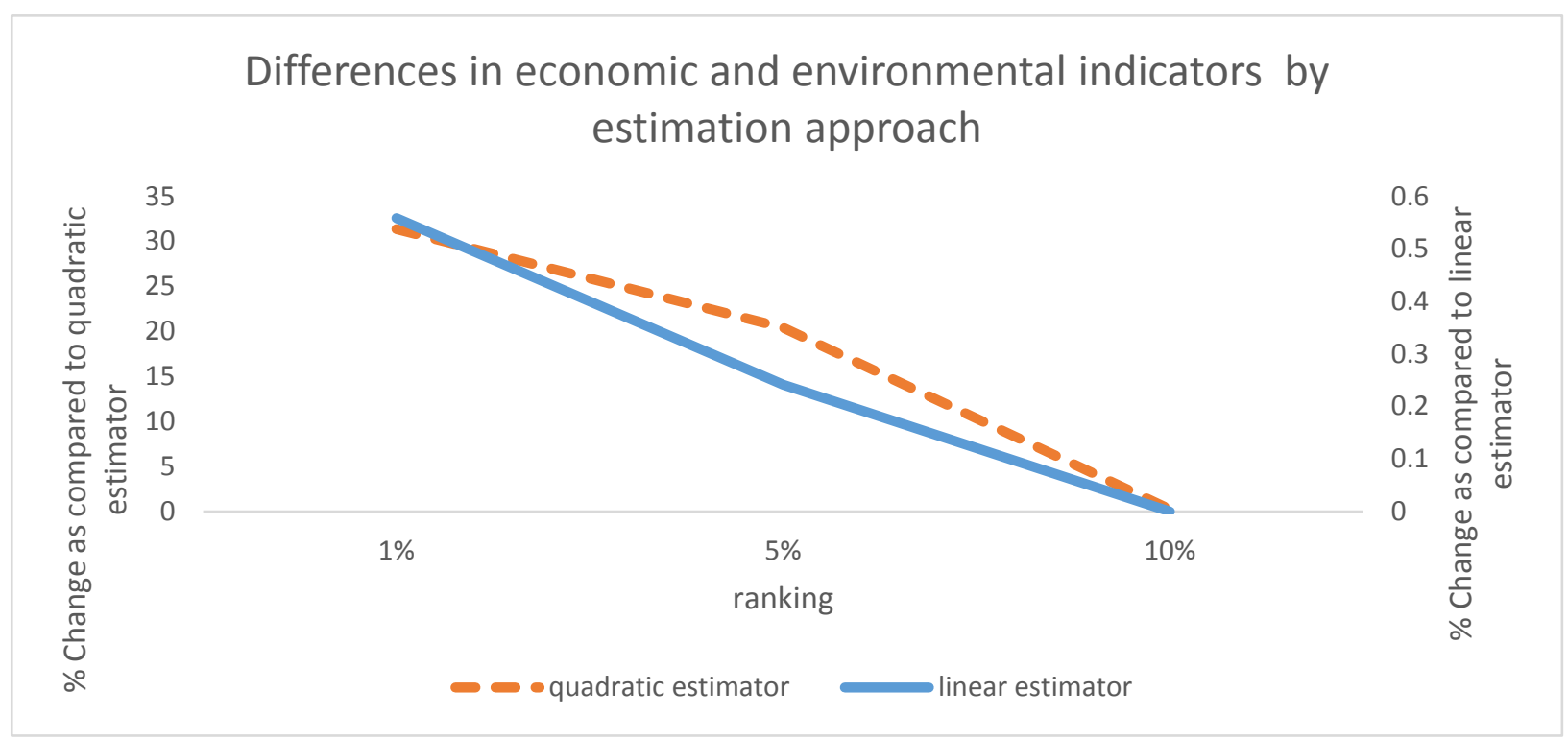

Figure 3. Differences in environmental and economic outcomes from linear and nonlinear estimator as compared

to multi-level model

\section{Conclusion}

As concerns continue to grow about the environmental impact of beef production, producers and researchers need to evaluate methods that can help to produce beef profitably while minimizing the effect on the environment. Using RFI (a measure of feed efficiency) as another selection criteria along with production traits can be an effective tool in achieving this objective. Historically, selection in beef cattle has focused on output traits resulting in differences in genetic improvements in these traits as compared to feed efficiency. Also, cattle are relatively less efficient as compared to other livestock-hogs and poultry. Breeding programs designed to improve the trait require the inclusion of both genotypic and phenotypic information. Even in the case of new DNA-based selection programs, phenotypic measurements are required in training population to validate genotypes. It is not unlikely that this may require data on cattle raised under different conditions and treatments. Feed intake however varies under the different conditions and the rigorous modelling of the different sources of heterogeneity can impact the accuracy of feed efficiency estimates. Given the multiplicity of factors that can influence feed intake, overfitting of conventional linear estimators can occur. This can negatively impact inferences made from parameter estimates. For feed efficiency, this can translate into errors in the ranking of the feed efficiency performance of cattle and the in selection of breeding stock for breeding. In this paper, we proposed and assessed the performance of a multi-level regression estimator and compared the feed efficiency rankings of cattle. Our results show that the ranking of cattle is sensitive to estimation approach. The multi-level estimator compared favorably with the conventional linear estimator when selections outcomes were assessed at the means of different percentiles. There were however minor deviations at the upper tail of the feed efficiency distribution where selection is most likely to occur. This suggests that the multi-level estimator can at the very least yield similar outcomes as conventional estimators whilst incorporating heterogeneity more robustly. We also assessed the economic and environmental impact of selection at different percentiles for the different estimators. This analysis was situated in the context of a feeding operation comprising 5600 animals. Our results show that selection for feed efficiency can increase net returns and reduce methane emission from enteric fermentation sources. A unit reduction in feed intake ( $\mathrm{kg}$ as fed/day) was associated with an average increase of $\$ 13.23$ in net returns and 33.46 tonnes reduction in emission at the end of the feeding period. On a percent intake basis, this translates into a $2.3 \%$ increase in net returns for each percent improvement in efficiency. This is lower than the $4.3 \%$ increase in profits reported in Fox, Tedeschi and Guiroy, (2001). The modelling assumptions in the two studies are not the same.

Selection for different traits in beef cattle requires performance data on multi-traits and genetic merit values. The genetic and phenotypic relationships with other traits are also considered together in formulating a breeding objective, and used to develop selection indices. Our focus on a single trait is limiting as we do not factor the economic implications of correlations with other traits. Ultimately, progeny performance is one input amongst 
many in the selection of breeding stock and our results must be interpreted keeping this caveat in mind. This notwithstanding, as showed in this study, rigorous empirical analysis of phenotypic data can have far-reaching implications.

\section{Acknowledgements}

Acknowledgements: Authors are grateful to Steve Miller and John Basarab for helpful comments and suggestions on an earlier draft of this paper. The usual disclaimer applies. Funding for this research was provided by Livestock Gentec and Genome Canada.

\section{References}

Alberta Agriculture and Food, (2008). The Beef Cow-calf Cattle Manual. Government of Alberta. Edmonton, $\mathrm{AB}$.

Alberta Agriculture and Rural Development, (2004). The drylot backgrounding of feeder cattle: Economic and productive performance. Retrieved May 21, 2015, from http://www1.agric.gov.ab.ca/\$department/deptdocs.nsf/all/econ8253

Angus Beef, (2015). Angus genetic trend by birth year. Retrieved May 21, 2015, from http://www.angus.org/nce/genetictrends.aspx

Archer, J. A., Richardson, E. C., Herd, R. M., \& Arthur, P. F. (1999). Potential for selection to improve efficiency of feed use in beef cattle: A review. Australian Journal Agricultural Research 50,147-161. http://dx.doi.org/10.1071/A98075

Arthur, P. F., Archer, J. A., Johnston, D. J., Herd, R. M., Richardson, E. C., \& Parnell, P. F. (2001). Genetic and phenotypic variance and covariance components for feed intake, feed efficiency, and other post-weaning traits in Angus cattle. Journal of Animal Science, 79, 2805-2811. https://doi.org/10.2527/2001.79112805x

Arthur, P. F., Renand, G., \& Krauss, D. (2001). Genetic and phenotypic relationships among different measures of growth and feed efficiency in young Charolais bulls. Livestock Production Science, 68(2), 131-139. https://doi.org/10.1016/S0301-6226 (00)00243-8

Babcock, A. H., Cernicchiaro, N., White, B. J., Dubnicka S. R., Thomson, D.U., Ives, S. E., Scott, H. M., Milliken, G. A., \& Renter. D. G. (2013). A multivariable assessment quantifying effects of cohort-level factors associated with combined mortality and culling risk in cohorts of U.S. commercial feedlot cattle. Preventive Veterinary Medicine, 108, 38-46. https://doi.org/10.1016/j.prevetmed.2012.07.008

Barker-Neef, J. M., Buskirk, D. D., Black, J. R., Doumit, M. E., \& Rust, S. R. (2001). Biological and economic performance of early-weaned Angus steers. Journal Animal Science 79, 2762-2769. http://dx.doi/10.2527/2001.79112762x

Basarab, J. A., Beauchemin, K. A., Baron, V. S., Ominski, K. H., Guan, L. L., Miller, S. P., \& Crowley, J. J. (2013). Reducing GHG emissions through genetic improvement for feed efficiency: effects on economically important traits and enteric methane production. Animal, 7(s2), 303-315. https://doi.org/10.1017/S1751731113000888

Basarab, J. A., Colazo, M. G., Ambrose, D. J., Novak, Mccartney, S., D., \& Baron, V. S. (2011). Residual feed intake adjusted for backfat thickness and feed frequency is independent of fertility in beef heifers. Canadian Journal Animal Science, 91, 573-584. https://doi.org/10.4141/cjas2011-010

Basarab, J. A., Price, M. A., Aalhus, J. L., Okine, E. K., Snelling, W. M., \& Lyle, K. L. (2003). Residual feed intake and body composition in young growing cattle. Canadian Journal of Animal Science, 83, 189-204. https://doi.org/10.4141/A02-065

Basarab, J., Baron, V., López-Campos, Ó., Aalhus, J., Haugen-Kozyra, K., \& Okine, E. (2012). Greenhouse gas emissions from calf-and yearling-fed beef production systems, with and without the use of growth promotants. Animal, 2, 195-220. https://doi.org/10.3390/ani2020195

Berry, D. P., \& Crowley, J. J. (2013). Genetics of feed efficiency in dairy and beef cattle. Journal of Animal Science, 91, 1594-1613. https://doi.org/10.2527/jas.2012-5862

Berthiaume, R., Mandell, I., Faucitano, L., \& Lafreniere, C. (2006). Comparison of alternative beef production systems based on forage finishing or grain-forage diets with or without growth promotants: 1 . Feedlot performance, carcass quality, and production costs. Journal of Animal Science, 84, 2168-2177. https://doi.org/10.2527/jas.2005-328 
Brelin, B., \& Brannang, E. (1982). Phenotypic and genetic variation in feed efficiency of growing cattle and their relationship with growth rate, carcass traits and metabolic efficiency. Swedish Journal of Agricultural Research, 12, 29-34.

Brody, S., (1945). Bioenergetics and Growth, with Special Reference to the Efficiency Complex in Domestic Animals. Reinhold Publishing Corp, New York.

Carlberg, J., \& Brown, W. J. (2001). An economic analysis of cow-calf retained ownership strategies. The Journal of the ASFMRA, 64-71.

Cernicchiaro, N., Renter, D. G., Xiang, S., White, B. J., \& Bello, N. M. (2013). Hierarchical Bayesian modeling of heterogeneous variances in average daily weight gain of commercial feedlot cattle. Journal of Animal Science, 91, 2910-2919. https://doi.org/10.2527/jas.2012-5543

Cooprider, K. L., Mitloehner, F. M., Famula, T. R., Kebreab, E., Zhao, Y., \& Van Eenennaam, A. L. (2011). Feedlot efficiency implications on greenhouse gas emissions and sustainability. Journal of Animal Science, 89, 2643-2656. http://dx.doi/10.2527/jas.2010-3539

Dilenzo, W., \& Lamb, G. C. (2012). Environmental and economic benefits of selecting beef cattle for feed efficiency. Department of animal science, Florida cooperative extension service, University of Florida, Florida.

Durunna, O. N., Mujibi, F. D. N., Goonewardene, L., Okine, E. K., Basarab, J. A., Wang, Z., \& Moore. S. S. (2011). Feed efficiency differences and re-ranking in beef steers fed grower and finisher diets. Journal of Animal Science, 89, 158-167. http://dx.doi/10.2527/jas.2009-2514

Environment Canada, (2012). Quantification protocol for selection for low residual feed intake in beef cattle. Retrieved May 21, 2015, from https://extranet.gov.ab.ca/env/infocentre/info/library/8562.pdf

Environment Canada, (2016). Understanding global warming potentials. Retrieved February 14, 2017, from https://www.epa.gov/ghgemissions/understanding-global-warming-potentials

Fluharty, F. L., Loerch, S. C., Turner, T. B., Moeller, S. J., \& Lowe, G. D. (2000). Effects of weaning age and diet on growth and carcass characteristics in steers. Journal of animal science, 78(7), 1759-1767. http://dx.doi/10.2527/2000.7871759x

Fox, D. G., Tedeschi, L. O., \& Guiroy, P. J. (2001). Determining feed intake and feed efficiency of individual cattle fed in groups: in Proc Beef Impr Fed 33rd Ann Res Symp Annu Meet, 33, 80-98.

Gelman, A., (2006). Multilevel (hierarchical) modeling: what it can and cannot do. Technometrics, 48. http://dx.doi.org/10.1198/004017005000000661

Hedeker, D., \& Gibbons, R. D. (1994). A random-effects ordinal regression model for multilevel analysis. Biometrics, 50, 933-944. http://dx.doi/10.2307/2533433

Hoque, M.A., Kadowaki, H., Shibata, T., Oikawa, T., \& Suzuki, K. (2009). Genetic parameters for measures of residual feed intake and growth traits in seven generations of duroc pigs. Livestock Science 121, 45-49. DOI: http://dx.doi.org/10.1016/j.livsci.2008.05.016

Johnson Z.B., Chewning J.J., \& Nugent, R.A. (1999). Genetic parameters for production traits and measures of residual feed intake in large white swine. Journal of Animal Science, 77, 1679-1685.

Koch, R. M., Swiger, L. A., Chambers D., \& Gregory K. E. (1963). Efficiency of feed use in beef cattle. Journal of Animal Science, 22, 486-494. http://dx.doi/10.2527/jas1963.222486x

Korver, S., (1988). Genetic aspects of feed intake and feed efficiency in dairy cattle: a review. Livestock Production Science, 20, 1-13. http://dx.doi.org/10.1017/S1751731113001687

Lawrence, J. D., \& Ibarburu, M. A., (2007). Economic analysis of pharmaceutical technologies in modern beef production. Iowa State University Agricultural Economic Research Report. Iowa State University, Ames.

Lu, D., Miller, S., Sargolzaei, M., Kelly, M., Vander Voort, G., Caldwell, T., Wang, Z., Plastow, G., Moore, S. (2013). Genome-wide association analyses for growth and feed efficiency traits in beef cattle. Journal Animal Science, 91, 3612-3633. http://dx.doi/10.2527/jas.2012-5716

Myers, S. E., Faulkner, D. B., Ireland, F. A., Berger, L. L., \& Parrett, D. F., (1999). Production systems comparing early weaning to normal weaning with or without creep feeding for beef steers. Journal of Animal Science, 77, 300-310. http://dx.doi/10.2527/1999.772300x

Ng, Z., Nkrumah, J. D., Li, C., Basarab, J. A., Goonewardene, L. A., Okine, E. K., \& Moore, S. S., (2006). Test 
duration for growth, feed intake, and feed efficiency in beef cattle using the GrowSafe System. Journal of Animal Science 84, 2289-2298.

Nkrumah, J. D., Basarab, J. A., Price, M. A., Okine, E. K., Ammoura, A., Guercio, S., \& Moore, S. S. (2004). Different measures of energetic efficiency and their phenotypic relationships with growth, feed intake, and ultrasound and carcass merit in hybrid cattle. Journal of Animal Science, 82, 2451-2459.

Rabe-Hesketh, S., \& Skrondal A., (2008). Multilevel and Longitudinal Modeling Using Stata. Stata Press, Texas.

Raudenbush, S.W. (1993). Hierarchical linear models and experimental design, in: Edwards, L.K.(Eds.), Applied Analysis of Variance in Behavioral Science. Marcel Dekker, New York, pp.459-495.

Rauw, W. M., Soler, J., Tibau, J., Reixach, J., \& Raya, L. G. (2006). Feeding time and feeding rate and its relationship with feed intake, feed efficiency, growth rate, and rate of fat deposition in growing Duroc barrows. Journal of Animal Science, 84, 3404-3409. http://dx.doi/10.2527/jas.2006-209

Robinson, D. L., (2005a). Determining the most accurate estimate of weight gain using feed efficiency data for cattle. Livestock Production Science, 95, 155-161.

Robinson, D. L., (2005b). Assessing the accuracy of modelling weight gain of cattle using feed efficiency data. Livestock Production Science, 95, 187-200. http://dx.doi/10.1016/j.livprodsci.2004.12.016

Schoonmaker, J. P., Fluharty F. L., \& Loerch S. C. (2004). Effect of source and amount of energy and rate of growth in the growing phase on adipocyte cellularity and lipogenic enzyme activity in the intramuscular and subcutaneous fat depots of Holstein steers. Journal of Animal Science, 82, 137-148.

http://dx.doi/10.2527/2004.821137x

Wileman, B. W., Thomson, D. U., Reinhardt, C. D., \& Renter, D. G., (2009). Analysis of modern technologies commonly used in beef cattle production: Conventional beef production versus nonconventional production using meta-analysis. Journal of Animal Science, 87, 3418-3426. http://dx.doi/10.2527/jas.2009-1778

\section{Copyrights}

Copyright for this article is retained by the author(s), with first publication rights granted to the journal.

This is an open-access article distributed under the terms and conditions of the Creative Commons Attribution license (http://creativecommons.org/licenses/by/3.0/). 